\title{
A Non-Parametric Analysis Of Efficiency Performances: The Case Of United Arab Emirates' Banks
}

Bruce Q. Budd, (E-mail: bruce.budd@zu.ac.ae), Zayed University, UAE

Catherine R. Budd, (E-mail: c.budd@ecu.edu.au), Edith Cowan University, Western Australia

\begin{abstract}
Competition and over-banking in the United Arab Emirates (UAE) indicates serious efficiency challenges facing the UAE banking sector prior to full compliance of the Bassel II capital accord in 2007. Using Data Envelopment Analysis (DEA), this paper investigates the relative efficiency measures. Six measures of efficiency performance are used: allocative, cost, pure technical, technical, scale and overall, using data from the annual financial reports from 1998 to 2002. Despite overall growing profits in the industry, results reveal evidence of over-banking and cost inefficiency in the money market. In particular, evidence suggests that regulatory and not managerial policy implications are attributed to poor cost efficiency results. Interestingly, and contrary to the benefits of economies of scale, the most efficient banks are not always the largest banks. Further evidence identifies contributory structural reasons for UAE banking inefficiency such as extensive capital adequacy ratios. At a time of growing global competition, data transparency and compliance with the World Trade Organisation, some individual banks need to address their financial positions to sustain high future profits.
\end{abstract}

\section{Introduction}

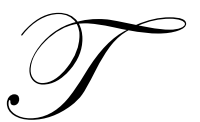

he UAE banking industry is gradually moving closer to western trends where banking is perceived as a package of services, which go beyond mere lending. Today the controversial debate of overbanking and efficiency performances reflects serious challenges facing the industry. Some bankers agree that 46 banks serving over 3 million people and with a per capita income of almost US $\$ 19,000$ is ample. Others advocate that the number of banks is irrelevant, provided they achieve profitable operations and adequate rates of growth. The aim of this research is to measure how efficient UAE banks are and to determine what structural factors influence their efficiency and performance. The methodologies employed are Data Envelopment Analysis (DEA), Malmquist index analysis and a series of second-stage regressions. Data from annual financial reports are used. Seventeen UAE banks between 1998 and 2002 are analysed. These banks represent all nonIslamic, national banks in UAE. The remaining three Islamic banks and 26 foreign banks are not included for reasons of limited availability of data and/or different financial procedures to regulatory compliance. A nonparametric approach using DEA is followed to estimate a variety of efficiency measures of each bank.

The peculiarity of the United Arab Emirates' (UAE) social structures has bestowed a great importance on the banking sector, not only because of the local demographic structure where foreign labour accounts for more than ninety per cent of the workforce, regularly transferring remittances to their home countries, but also because the high per capita income, and high margin of savings. Regulations are now broadening to encourage investment, equity and property ownership to non-nationals, albeit limited. The banks are the central intermediaries for the vast oilbased wealth of the ruling families and source of capital investment within the country. Within a challenging climate of financial transparency and limited data availability, the contribution of this paper provides a benchmark and a unique table of efficiency performances, for comparative analysis between banks in the UAE for 2002 for present and future policymakers and researchers. A further contribution reveals what structural factors may influence their overall efficiency and managerial performances. Section two provides a literature review; section 
three explains the methodology of DEA, and data analysis. Section four describes the conceptual framework and analysis. Section five reports the empirical results. Section six provides conclusions.

\section{Literature Review}

Farrell (1957) shows how 'overall efficiency' can be decomposed into 'price efficiency' and 'technical efficiency'. Charnes, Cooper, and Rhodes, (1978) based on the work of Farrell (1957), introduces the DEA approach and their research provides the basis for all subsequent developments in the nonparametric approach to the measurement of technical efficiency. Banker, Charnes, and Cooper, (1984), shows that the efficiency measure developed by Charnes et al. (1978) can be divided into 'pure technical' and 'scale' efficiencies. The evidence indicates that banks are generally inefficient, although small banks perform better than larger banks on the efficiency score (Ferrier and Lovell [1990], Elyasiani and Mehdian [1990], and Noulas [1997]). The literature on efficiency and productivity performances of financial institutions is vast. More recent studies examine efficiency and productivity changes in financial institutions. Notable among them include those by Altunbus, Liu, Molyneux, and Seth, (1999) for Japan, Isik and Hassan (2000) for Turkey, Rebelo and Mendes (2000) for Portugal, Chen, Tseryieth (2002) for Taiwan, and Darrat, Topuz, and Yousef, (2002) for Kuwait. No published evidence is found of research of UAE banks using a nonparametric DEA.

\section{Methodology And Data Analysis}

This analysis uses three input variables, their unit prices, and two output variables. The product of inputs times outputs in DEA application should optimally be less than the sample size (in this case, 17 banks), in order to discriminate among banks. Examples of DEA studies that also use small samples include: Avkiran, (1999) uses 16 to 19 for Australia; Darrat, Topuz and Yousef, (2002) uses 8 for Kuwait; Giokas, (1991) uses 17 for Greece; Oral and Yolalan, (1990) uses 20 for Turkey and Vassiloglu and Giokas, (1990) uses 20 for Greece. The input variables are: total number of full-time employees (L), total capital (K), (book value of land, premises and equipment and other assets), and total deposits (D), (deposit liabilities due to banks and customers deposits). In addition input prices are incorporated specifically to measure allocative efficiency. The unit price of labour (PL) is the total cost of all banks' employees (staff expenses) divided by the total number of employees. The unit price of capital (PK) is measured by the division of total capital by other operating expenses. The unit price of deposits (PD) is computed by the total interest expenses of deposits divided by total deposits. The two output variables are: total loans (LA), (loans and advances to customers) and total investments $(\mathrm{H})$, (value of all securities other than those held in the bank's accounts, i.e. treasury bills, government debt, bonds and investment securities).

The UAE have the second largest banking sector in the Arab world after Saudi Arabia in terms of assets and capital. The assets of the national banks account for nearly 75 per cent of the total assets of all banks in the UAE, standing at US\$72 billion in September 2003. The bulk of the capital increase is from national banks since foreign institutions are required only to keep a minimum capital of US\$10.9 million on the grounds they are operating as branches in the UAE (Central Bank of United Arab Emirates Annual Report 2002). All UAE banks attract funds since they act the dual role of intermediaries for both the money and capital markets. In the absence of a corporate bond market, funds that would have otherwise channeled into equity and bond markets have traditionally accumulated substantial bank deposits. In addition national banks have maintained a strong and robust financial position enjoying the unique luxury of high income from limited non-interest bearing accounts protected from foreign competition, but global changes could reverse this in absence of reforms. The implementation of the Basel II capital accord, which becomes effective in 2007, will demand that banks have the technology to capture, report and store data, and determine the minimum level of capital required. This will have the effect of exposing banks to public scrutiny and change the profile of risk assessment and traditional operational management practices in banking.

Table 1 shows the descriptive statistics of variables used for the DEA. The average number of full-time employees of the 17 sample banks is 700 people in 2002. The unit price of labour, that is, the price per person per year, is US $\$ 37,751$ in 2002. The unit price of capital and deposits, respectively, is US\$7,921 and US\$16,385 in 2002. The trend for the unit price of labour is predictably increasing with the increase demand for staff. The trend 
for the unit price of labour is increasing with the increase demand for staff. The unit price of capital is falling as improving information technology is adopted, reducing operating expenses. The unit price of deposits is also falling due to falling interest rates.

Table 1

Descriptive Statistics Of 17 UAE National Banks 1998 - 2002.

\begin{tabular}{|c|c|c|c|c|c|}
\hline Year & 1998 & 1999 & 2000 & 2001 & 2002 \\
\hline \multirow[b]{3}{*}{ Outputs } & Mean & Mean & Mean & Mean & Mean \\
\hline & (Std. Dev.) & (Std. Dev.) & (Std. Dev.) & (Std. Dev.) & (Std. Dev.) \\
\hline & US millions & US millions & US millions & US millions & US millions \\
\hline \multirow{2}{*}{ Loans } & 1324.45 & 1413.28 & 1462.06 & 1536.06 & 18802.62 \\
\hline & $(1520.87)$ & $(1545.69)$ & $(1624.25)$ & $(1692.41)$ & $(2047.32)$ \\
\hline \multirow{2}{*}{ Investments } & 418.32 & 389.34 & 344.61 & 437.70 & 477.59 \\
\hline & (951.16) & (903.37) & (534.53) & (698.35) & $(880.60)$ \\
\hline \multicolumn{6}{|l|}{ Inputs } \\
\hline \multirow{2}{*}{ Labour } & 686 & 689 & 679 & 688 & 700 \\
\hline & $(729)$ & (699) & $(674)$ & $(629)$ & $(615)$ \\
\hline \multirow{2}{*}{ Capital } & 568.17 & 647.90 & 595.60 & 946.04 & 1203.81 \\
\hline & (698.30) & $(767.30)$ & (751.38) & (721.89) & (1601.57) \\
\hline \multirow{2}{*}{ Deposits } & 2014.43 & 2069.62 & 2293.10 & 2508.54 & 2679.92 \\
\hline & $(2428.91)$ & $(2354.75)$ & (2657.44) & $(2624.52)$ & $(2965.75)$ \\
\hline \multicolumn{6}{|l|}{ Input Prices } \\
\hline \multirow{2}{*}{ PL } & 0.030685 & 0.032959 & 0.033609 & 0.034149 & 0.037751 \\
\hline & $(0.007507)$ & $(0.008083)$ & $(0.007233)$ & $(0.038168)$ & $(0.008114)$ \\
\hline \multirow{2}{*}{ PK } & 0.013271 & 0.017141 & 0.014517 & 0.033180 & 0.007921 \\
\hline & $(0.010466)$ & $(0.023444)$ & $(0.009694)$ & $(0.080081)$ & $(0.005254)$ \\
\hline \multirow{2}{*}{ PD } & 0.041999 & 0.040305 & 0.047419 & 0.035248 & 0.016385 \\
\hline & $(0.006279)$ & $(0.006534)$ & $(0.008914)$ & $(0.008513)$ & $(0.004943)$ \\
\hline \multirow[t]{2}{*}{ Total Assets } & 2457.42 & 2235.142 & 2803.684 & 2964.695 & 3298.06 \\
\hline & (2868.25) & (2710.599) & $(3118.076)$ & $(3180.891)$ & (3551.72) \\
\hline \multirow{2}{*}{$\begin{array}{l}\text { Total } \\
\text { Liabilities }\end{array}$} & 2121.271 & 2166.232 & 2389.257 & 2514.541 & 2809.29 \\
\hline & $(2576.660)$ & $(2464.108)$ & $(2757.819)$ & $(2769.172)$ & $(3088.04)$ \\
\hline
\end{tabular}

\section{Conceptual Framework And Analysis}

DEA is a linear programming based technique for measuring the relative performance of organizational units or decision making units such as banks, which share the same technology for similar outputs using similar inputs. This technique is a non-parametric, deterministic methodology for determining relatively efficient production frontier, based on the empirical data on the chosen inputs and outputs of a number of banks. From the set of available data, DEA identify reference points, relatively efficient banks, that define the efficient frontier as the best practice production technology, and evaluate the inefficiency of other points, which are the relatively inefficient banks that are below that frontier. The efficiency scores of banks vary between one, the most efficient, and zero, the least efficient. The objective of different DEA models is to determine which bank establishes the best efficiency frontier.

Based on the Charnes et. al., (1978) model, and following Darrat et. al. (2002:6) derivation, the mathematical model is as follows. Given there are $n$ banks, utilizing $m$ different inputs, to produces different outputs, cost efficiency for a particular bank $(j)$ is calculated assuming the minimum cost of producing outputs $(O)$, given input prices $(w)$. This minimum cost is calculated by the following linear programming problem: 
$\operatorname{Min}_{I_{i}} \sum_{i=1}^{m} w_{i} I_{i}$

subject to $\quad \sum_{j=1}^{n} \lambda_{j} O_{r j} \geq O_{r j o}$,

$$
\begin{aligned}
& \sum_{j=1}^{n} \lambda_{j} I_{i j} \leq I_{i j o} \\
& \sum_{j=1}^{n} \lambda_{j}=1 \\
& \lambda_{j} \geq 0 .
\end{aligned}
$$

where for bank $j, \lambda_{j}$ and $w_{j}$ are the intensity variables and input prices, respectively. $\mathrm{O}_{\mathrm{rj}}$ is the $r^{\text {th }}$ output variable of the bank; $I_{i j}$ is the $i^{\text {th }}$ input variable of the bank; $O_{r j o}$ is its observed output vector; and $I_{i j o}$ is its observed input vector. Cost efficiency for bank $j$ is measured by the ratio of minimum cost to actual cost incurred by the bank. In order to calculate technical efficiency for bank $j$, the following linear programming problem is solved:

\section{$\operatorname{Min} \Theta$,}

$$
\begin{array}{ll}
\text { subject to } \quad & \sum_{j=1}^{n} \lambda_{j} O_{r i} \geq O_{r j o}, \\
& \sum_{j=1}^{n} \lambda_{j} I_{i j} \leq \Theta . I_{i j 0}, \\
& \lambda_{j} \geq 0 .
\end{array}
$$

Finally to allow for variable returns to scale, using the BCC model, another constraint must be added:

$$
\sum_{j=1}^{n} \lambda_{j}=1
$$

\section{$5 \quad$ Empirical Results}

Using the DEA and data from the 17 UAE banks, efficiency measures are computed. Table 2 shows the individual banks' means of their respective annual efficiency scores and descriptive statistics of the industry's scores. The individual allocative efficiency and cost efficiency mean scores of 0.85 and 0.78 , respectively. Cost efficiency measures the possible theoretical cost reductions that can be achieved when a bank is technically efficient as well as allocatively efficient. The technical efficiency score of 0.89 relates to the ability of banks to minimize costs and maximize revenues. The results suggest that the cost inefficiency mean of 22 per cent may be attributed to regulatory (not managerial) policy implications of the UAE national banks. In addition there is no evidence that small banks are necessarily more cost efficient than larger banks. It is apparent that there is a wide disparity between efficiency scores and banks, which may suggest over-banking in a limited market. These results imply that UAE banks do a better job utilizing available inputs than choosing the proper input mix. There is no difference between pure technical and scale efficiencies, which are relatively high. The overall efficiency score for all banks is 0.76 , reflecting a mean score of 24 per cent inefficiency. The lowest individual banks are National Bank of Dubai (0.48), which possesses one of the greatest proportions of total assets in the sample, and Arab Bank for Investment and 
Trade (0.55), which possesses one of the lower proportions of total assets. The highest overall efficiency score is Abu Dhabi Commercial Bank (0.91). Nevertheless the mean is higher than the overall mean (0.73) of data citied by Berger and Humphrey (1997)'s for other cross-country research of many banks using DEA technique.

Table 2 Efficiency Scores For All National Banks.

\begin{tabular}{|c|c|c|c|c|c|c|}
\hline \multirow[b]{3}{*}{ Banks } & \multicolumn{6}{|c|}{ Mean $1998-2002$} \\
\hline & \multicolumn{2}{|c|}{ BBC Model VRS } & \multicolumn{3}{|c|}{ CCR Model CRS } & \multirow{2}{*}{$\begin{array}{c}\text { TE*CE } \\
\text { OE }\end{array}$} \\
\hline & PTE & SE & TE* & $\begin{array}{c}\mathbf{A E}=\mathrm{CE} / \mathrm{T} \\
\mathrm{E}\end{array}$ & $\mathbf{C E}$ & \\
\hline Abu Dhabi Commercial Bank & 0.98 & 1.00 & 0.98 & 0.92 & 0.91 & 0.91 \\
\hline Arab Bank for Investment \& Foreign Trade & 0.98 & 1.00 & 0.69 & 0.80 & 0.56 & 0.55 \\
\hline Bank of Sharjah & 0.78 & 0.85 & 0.88 & 0.93 & 0.82 & 0.82 \\
\hline Commercial Bank International & 1.00 & 0.88 & 0.95 & 0.91 & 0.87 & 0.87 \\
\hline Commercial Bank of Dubai & 0.98 & 0.97 & 0.87 & 0.90 & 0.80 & 0.78 \\
\hline Emirates Bank Intel. & 0.90 & 0.96 & 0.93 & 0.92 & 0.87 & 0.85 \\
\hline First Gulf Bank & 0.99 & 0.94 & 0.97 & 0.83 & 0.80 & 0.80 \\
\hline Investbank & 0.99 & 0.97 & 0.99 & 0.83 & 0.83 & 0.82 \\
\hline MashreqBank & 0.99 & 1.00 & 0.82 & 0.88 & 0.78 & 0.72 \\
\hline National Bank of Abu Dhabi & 0.85 & 0.96 & 0.99 & 0.80 & 0.79 & 0.79 \\
\hline National Bank of Dubai & 1.00 & 0.99 & 0.82 & 0.59 & 0.68 & 0.48 \\
\hline National Bank of Fujairah & 0.89 & 0.92 & 0.90 & 0.81 & 0.75 & 0.73 \\
\hline National Bank of Ras Al Khaima & 0.98 & 0.91 & 0.91 & 0.85 & 0.78 & 0.78 \\
\hline National Bank of Sharjah & 0.96 & 0.95 & 0.81 & 0.92 & 0.81 & 0.75 \\
\hline National Bank of Umm Al Qaiwan & 0.97 & 0.82 & 0.88 & 0.85 & 0.76 & 0.75 \\
\hline United Arab Bank & 0.94 & 0.93 & 0.87 & 0.92 & 0.82 & 0.80 \\
\hline Union National Bank & 0.89 & 0.97 & 0.89 & 0.82 & 0.74 & 0.72 \\
\hline UAE bank sample mean & 0.94 & 0.94 & $\mathbf{0 . 8 9}$ & 0.85 & 0.78 & 0.76 \\
\hline Standard deviation & 0.015 & 0.052 & 0.078 & 0.082 & 0.079 & 0.106 \\
\hline Minimum & 0.78 & 0.81 & 0.69 & 0.59 & 0.56 & 0.48 \\
\hline Maximum & 1.00 & 1.00 & 1.00 & $0.93 * *$ & $0.91 * *$ & $0.91 * *$ \\
\hline \multicolumn{7}{|c|}{$\begin{array}{l}\text { *Results for Technical Efficiency (TE) are identical for } C C R \text { and } B B C \text { models. } \\
* * \text { These figures are the means of efficiency scores over } 5 \text { years and therefore do not necessarily equal } 1.00 \\
\text { PTE = pure technical efficiency; } S E=\text { scale efficiency; } T E=\text { technical efficiency; AE= allocative efficiency; CE = cost } \\
\text { efficiency; OE = Overall economic efficiency. }\end{array}$} \\
\hline
\end{tabular}

To investigate, more specifically, the banks' productivity changes over time, a further useful instrument within the DEA framework called the Malmquist Index (MI) (1953) is followed. The advantage of the Malmquist index is that it does not require a profit maximization or cost minimization assumption. Secondly, it is the preferred method when inputs, outputs and price information are not available. Lastly, if panel data are available, the productivity changes can be decomposed into technical efficiency change (also called the catching up index) and the technical change (also called the changes in the best practice index). Its drawback is that it requires the computation of distance function. However, the linear programming technique of DEA can be used to solve the problem (Fare, Grosskopf, Lovell, [1994]). The index is the product of two elements: the change in technical efficiency, or how close a bank can get to the efficient frontier (catching up), and technological change, or how much the benchmark production frontier shifts at each bank's observed input mix (innovations shocks). A Malmquist index that is greater than one implies that total factor productivity progress has occurred, while an index less than one means that total factor productivity has fallen. Refer to Coelli et al. (1998) for a more lucid explanation. Results in Table 4 suggest that UAE banks collectively are not improving overall performance. This evidence suggests efficiency performances remain a serious issue within the UAE money market. Technical efficiency change, technological change and pure technical efficiency change have all fallen relatively, contributing to the total factor productivity change decline. Only scale efficiency change reports any overall positive improvement, albeit slight. 
Table 3 Malmquist Index Summary Of Annual Means

\begin{tabular}{|l|c|c|c|c|c|}
\hline Year & $\begin{array}{c}\text { Technical efficiency } \\
\text { change } \\
\text { (TEC) }\end{array}$ & $\begin{array}{c}\text { Technological } \\
\text { change } \\
\text { (TC) }\end{array}$ & $\begin{array}{c}\text { Pure technical } \\
\text { efficiency change } \\
\text { (PTEC) }\end{array}$ & $\begin{array}{c}\text { Scale efficiency } \\
\text { change } \\
\text { (SC) }\end{array}$ & $\begin{array}{c}\text { Total factor } \\
\text { productivity } \\
\text { (TFP) }\end{array}$ \\
\hline 1999 & 1.114 & 0.856 & 1.057 & 1.055 & 0.954 \\
\hline 2000 & 0.991 & 1.109 & 1.014 & 0.977 & 1.099 \\
\hline 2001 & 0.991 & 0.965 & 0.988 & 1.004 & 0.957 \\
\hline Geometric Mean & 0.794 & 1.037 & 0.816 & 0.974 & 0.824 \\
\hline
\end{tabular}

The final and crucial contribution of this research is to undertake an exploratory empirical testing of the structure-performance hypothesis that the concentration of banks plays a significant role in determining bank profitability (Scweiger and McGee (1961). According to the Structural-Performance hypothesis, the structure characteristics of the bank market have a clear impact on the costs of bank credit and ultimate competitiveness of lending and business investments. Further insights may explain the efficiency values measured by DEA. A secondstage regression analysis follows. The explanatory variables for banking structures are classified under five proxies: bank size, profitability, market power, risk and capitalization. The bank size is measured by total assets. Profitability by four financial ratios of: earnings per share, returns of equity; net income; and the ratio net income to total assets. Market power is the ratio of individual banks' total deposits to total deposits of all banks. Risk is measured by two ratios: loans to total assets, and the capital adequacy ratio of total equity to total assets. The loans to total asset ratio may influence operating efficiency. Typically loans are more costly and more risky than purchasing securities therefore banks may be less cost efficient the higher the banks' capitalization ratio. In addition the risk ratios act as a proxy for banks' attitude to risk aversion. The greater the ratio, the higher the bank's capital and attitude to risk. The banks' capitalization is measured by total equity.

Table 4 shows the results from six second-stage regressions. The loan ratio shows a statistically significant and positive relationship to technical and scale efficiencies, and a negative relationship to the dependent variable allocative efficiency, (which includes inputs costs). The positive sign shows a more efficient bank with relative lower loan costs to total assets. Relatively efficient firms that are able to manage operations more productively, would have lower production costs and, in turn, offer more reasonable loan terms and gain market shares. The negative sign may suggest allocative inefficiency. Further, both the capital adequacy ratio and the loans ratio (proxies for risk) were mostly negative and significant showing a tendency for risk aversion. The capital adequacy, the ratio between shareholders' equity and assets, is high on world standards. Particularly since the crisis in the early 1990s caused by an accumulation of failed bad debts after extended loans during the early oil boom in the early 1980s, banks have heeded Central Bank instructions strengthening their reserves and tightening credit rules.

The adequacy ratio acts as a proxy for banks' attitude to risk. In face of global competition, the UAE banks are safeguarding their reserves. Banks with large market concentration power may incline to rely on the loans which are less profitable and possibly, less risky. In addition, the changing composition of the banks loan portfolio and resulting efficiency measures might be generated by the crucial obligations of entry requirements of the Bassel Core Principles for the World Trade Organization. Similar to Isik and Hassan (2000) for Turkey, and Darrat et. al. (2002) for Kuwait, the results for bank size shows a negative significance of efficiency and scale. That is, large banks are not necessarily efficient banks. On the other hand, unlike the findings by Darrat et. al. (2000), Hasan and Marton (2000) and Noulas (1997), market power shows no significance in the measures of efficiencies (except scale and allocative efficiency) in this sample. Considering the highly regulated framework of commercial banks in UAE, this may be a factor that cannot be easily adjusted by individual banks. Capitalization of UAE banks' is positive and significant. This is consistent with Berger and Mester (1997), though contrasts with Darrat et. al. (2002) for Kuwait for the period 1994 and 1998. 
Table 417 UAE Banks Second-Stage Regression Results, 2002

\begin{tabular}{|c|c|c|c|c|c|c|}
\hline VARIABLES & PTE & SE & TE & $\mathbf{A E}$ & $\mathbf{C E}$ & OE \\
\hline Constant & $\begin{array}{l}0.867 * * \\
(2.666) \\
\end{array}$ & $\begin{array}{l}0.648 * * \\
(1.995) \\
\end{array}$ & $\begin{array}{l}0.576^{*} \\
(1.647) \\
\end{array}$ & $\begin{array}{l}1.529 * * * \\
(9.888)\end{array}$ & $\begin{array}{c}1.188 * * * \\
(3.360)\end{array}$ & $\begin{array}{c}1.188 * * * \\
(3.630)\end{array}$ \\
\hline \multicolumn{7}{|l|}{ Proxy For Bank Size } \\
\hline Total Assets & $\begin{array}{l}8.127 * \\
(1.351) \\
\end{array}$ & $\begin{array}{l}-2.664 \\
(-0.809) \\
\end{array}$ & $\begin{array}{c}1.573 \\
(0.483) \\
\end{array}$ & $\begin{array}{c}2.663 \\
(0.995) \\
\end{array}$ & $\begin{array}{c}3.240 \\
(1.089) \\
\end{array}$ & $\begin{array}{c}3.240 \\
(1.089) \\
\end{array}$ \\
\hline \multicolumn{7}{|l|}{ Proxy For Profitability } \\
\hline$E P S$ & $\begin{array}{c}0.303 \\
(1.085)\end{array}$ & $\begin{array}{c}0.189 \\
(1.238)\end{array}$ & $\begin{array}{c}0.294 * * \\
(1.946)\end{array}$ & $\begin{array}{c}0.245 * * \\
(1.971)\end{array}$ & $\begin{array}{c}0.345 * * \\
(2.499)\end{array}$ & $\begin{array}{c}0.345 * * \\
(2.499)\end{array}$ \\
\hline$R O E$ & $\begin{array}{l}-0.813 \\
(-1.057)\end{array}$ & $\begin{array}{l}-0.113 \\
(-0.268)\end{array}$ & $\begin{array}{l}-0.431 \\
(-1.036)\end{array}$ & $\begin{array}{c}-1.399 * * * \\
(-4.088)\end{array}$ & $\begin{array}{l}-0.966 * * \\
(-2.542)\end{array}$ & $\begin{array}{l}-0.966 * * \\
(-2.542)\end{array}$ \\
\hline Net Income & $\begin{array}{l}-6.271 * * \\
(-1.826) \\
\end{array}$ & $\begin{array}{l}-3.119^{*} \\
(-1.660) \\
\end{array}$ & $\begin{array}{c}-5.388 * * * \\
(-2.898)\end{array}$ & $\begin{array}{c}-0.785 \\
(-0.514) \\
\end{array}$ & $\begin{array}{l}-4.440 * * \\
(-2.615)\end{array}$ & $\begin{array}{l}-4.440 * * \\
(-2.615) \\
\end{array}$ \\
\hline Net Income/Total Assets & $\begin{array}{l}1.828 * * \\
(2.117)\end{array}$ & $\begin{array}{c}0.127 \\
(0.270)\end{array}$ & $\begin{array}{c}0.904 * * \\
(1.935)\end{array}$ & $\begin{array}{l}0.972 * * \\
(2.529)\end{array}$ & $\begin{array}{l}1.135 * * \\
(2.660)\end{array}$ & $\begin{array}{l}1.135^{* *} \\
(2.660)\end{array}$ \\
\hline \multicolumn{7}{|l|}{ Proxy For Market Power } \\
\hline \begin{tabular}{|l|} 
Mkt. Share \\
Deposits/Total Deposits
\end{tabular} & $\begin{array}{l}-3.410 \\
(-0.784) \\
\end{array}$ & $\begin{array}{c}3.067 \\
(1.238) \\
\end{array}$ & $\begin{array}{c}0.938 \\
(0.398) \\
\end{array}$ & $\begin{array}{l}-3.724 * * \\
(-1.924) \\
\end{array}$ & $\begin{array}{c}-1.663 \\
(-0.773) \\
\end{array}$ & $\begin{array}{l}-1.663 \\
(-0.773) \\
\end{array}$ \\
\hline \multicolumn{7}{|l|}{ Proxy For Risk } \\
\hline Capital Adequacy & $\begin{array}{l}-1.381 * \\
(-1.401)\end{array}$ & $\begin{array}{l}-0.723^{*} \\
(-1.340)\end{array}$ & $\begin{array}{l}-1.182 * \\
(-2.216)\end{array}$ & $\begin{array}{c}-2.196 * * * \\
(-5.006)\end{array}$ & $\begin{array}{l}-1.869 * * * \\
(-3 . .835)\end{array}$ & $\begin{array}{c}-1.869 * * * \\
(-3.835)\end{array}$ \\
\hline Loans/Total Assets & $\begin{array}{c}-0.362 \\
(-0.671)\end{array}$ & $\begin{array}{l}0.803 * * \\
(2.716) \\
\end{array}$ & $\begin{array}{l}0.464 * \\
(1.587) \\
\end{array}$ & $\begin{array}{c}-0.682 * * * \\
(-2.836)\end{array}$ & $\begin{array}{c}-0.089 \\
(-0.334) \\
\end{array}$ & $\begin{array}{c}-0.089 \\
(-0.334) \\
\end{array}$ \\
\hline \multicolumn{7}{|l|}{ Proxy For Capitalization } \\
\hline Total Equity & $\begin{array}{c}1.800 \\
(0.931) \\
\end{array}$ & $\begin{array}{c}3.015 * * * \\
(2.850)\end{array}$ & $\begin{array}{c}3.232 * * * \\
(3.089)\end{array}$ & $\begin{array}{l}1.663 * * \\
(1.933)\end{array}$ & $\begin{array}{c}3.028 * * * \\
(3.168) \\
\end{array}$ & $\begin{array}{c}3.028 * * * \\
(3.168)\end{array}$ \\
\hline Adj. $\mathbf{R}^{2}$ & 0.040 & 0.712 & 0.719 & 0.810 & 0.765 & 0.765 \\
\hline F. Stat. & 1.074 & 5.405 & 5.541 & 8.574 & 6.799 & 6.799 \\
\hline D.W. & 2.047 & 2.452 & 1.505 & 1.871 & 1.537 & 1.537 \\
\hline
\end{tabular}

\section{Conclusions}

In this paper efficiency measures for 17 national, non-Islamic, UAE commercial banks between the years 1998-2002 are examined. Empirical results from the DEA show no distinct overall improvement change in relative efficiencies of the banks over time. This is a crucial and interim stage of UAE banking development towards global competition. The compliance of the Basell II accord will gradually expose banks to more public scrutiny and change traditional operational management practices in banking. Under the aegis of domestic regulations, evidence identifies over-banking as one of the contributory factors towards poor efficiency results of some banks. Profits are high, but their efficiency levels for some banks are not. These results are objective and replicable multidimensional measures of banking system development. In a country that remains lacking in financial transparency and accuracy of data collection, the ability of these banks to sustain future profitability levels, now depends on how efficient they are. 


\section{References}

1. Altunbas, Y. Liu, M. H. Molyneux, P. and Seth, R. "Efficiency and Risk in Japanese Banking", Journal of Banking and Finance, 24, 10 (1999), p.1605-1628.

2. Avkiran, N. K. "The Evidence on Efficiency Gains: The Role of Mergers and the Benefits to the Public", Journal of Banking and Finance, 23, (1999), p.991-1013.

3. Banker, R.D., Charnes, A. and Copper, W.W. "Some Models for Estimating Technical and Scale Inefficiencies in Data Envelopment Analysis". Management Sciences, 30(9), (1984), p.1078-1092.

4. Berger, A.N. and Humphrey, D.B. "Efficiency of Financial Institutions: International Survey and Directions for Future Research”. European Journal of Operational Research, 98, (1997), p.175-212.

5. Berger A.N. and Mester, L.J. "Inside the Black Box: What Explains Differences in the Efficiencies of Financial Institutions?" Journal of Banking and Finance, 21, (1997) p.895-947.

6. Central Bank of United Arab Emirates Annual report 2002, http://www.uaecb.gov.ae/ accessed December 2003.

7. Charnes, A., Cooper, W.W. \& Rhodes, E. "Measuring the Efficiency of Decision Making Units". European Journal of Operational Research, 2, (1978), p.429-444.

8. Chen, Tser-yieth. "A Comparison of Chance-constrained DEA and Stochastic Frontier Analysis: Bank Efficiency In Taiwan". Journal of the Operational Research Society (2002), 53, pp.492-500.

9. Coelli, T., Rao, D.S.P., and Battese, G.E. "An Introduction to Efficiency and Productivity Analysis". Boston: Kluwer Academic Publishers. (1998).

10. Darrat, A.F., Topuz, C. and Yousef, T. "Assessing Cost and Technical Efficiency of Banks in Kuwait". ERF's $8^{\text {th }}$ Annual Conference in Cairo, (2002).

11. Fare, R., Grosskopf, S., Lovell, C.A.K. Production Frontiers, Cambridge, MA: Cambridge University Press. (1994).

12. Farrell, M.J. "The Measurement of Productive Efficiency". Journal of the Royal Statistical Society Series A, 120, (1957), p.253-281.

13. Ferrier, G.D., and C.A.K. Lovell, "Measuring Cost efficiency in Banking: Econometric and Linear Programming Evidence". Journal of Econometrics 46, (1990), p.229-245.

14. Giokas, D. "Bank Branch Operating Efficiency: A Comparative Application of DEA and the Loglinear Model". Omega International Journal of Management Science, 19, (1991), p.549-557.

15. Haag, S.E. and Jaska, P.V. "Interpreting Inefficiency Ratings: An Application of Bank Branch Operating Efficiencies". Managerial and Decision Economics, 16, (1995), p.7-14.

16. Hasan, I., and Marton, K. "Development and Efficiency of the Banking Sector in a Transitional Economy: Hungarian Experience", Stern School of Business, New York University, (2000), Working Paper.

17. Isik, I. and Hassan, M.K. "The Effect of the 1994 Economic Crisis on the Productivity and Efficiency of Turkish Banks". School of Management, New Jersey Institute of Technology, (2000), Working Paper 3.

18. Kawach, N., "UAE Banks Beef Up Capital and Reserves", Gulf News, daily newspaper, United Arab Emirates, 24 March 2004, page 34.

19. Malmquist, S. Index Numbers and Indifferent Curves. Trabajos de Estatistica, 4, 1, (1953), p.209-42.

20. Miller, S.M. and Noulas, A.G. "The technical Efficiency of Large Bank Production". Journal of Banking and Finance, 20, (1996), p.495-509.

21. Noulas, A.G., "Productivity Growth in the Hellenic Banking Industry: State Versus Private Banks". Applied Financial Economics, 7, (1997), p.223-228.

22. Oral, M. Yolalan, R. "An Empirical Study on Measuring Operating Efficiency and Profitability of Bank Branches". European Journal of Operational Research, 46, (1990), p.282-294.

23. Rebelo, J., and Mendes, L., "Malmquist Indices of Productivity Change in Portuguese Banking: The Deregulation Period" International Advances in Economic Research 6, i3 (August 2000), p.531.

24. Schweger, I., and McGee, J.S., "Banking: The Structure and Performance of Banks and Related Financial Institutions in Chicago and Other Areas", Journal of Business, 34, 17(1), (1961), p.69-83.

25. Vassiloglu, M. and Giokas, D. "A Study of the Relative Efficiency of Bank Branches: An Application of Data Envelopment Analysis". Journal of the Operational Research Society, 41, (1990), p.591-597. 